\title{
ThE 2016 Municipal ELECTIONS
}

\author{
Vincenzo Emanuele and Nicola Maggini
}

The municipal elections held in June 2016 involved around 15 million voters and 1,342 councils, of which 143 had more than 15,000 inhabitants, including the four largest cities in the country (Rome, Milan, Naples, and Turin). Looking beyond the number and importance of the councils involved, this round of elections was particularly significant because it fell halfway through an electoral cycle that had begun in 2013 with the historic success of the Movimento 5 Stelle (M5S, Five Star Movement) in the general election (Maggini and De Lucia 2014; Tronconi 2015a), which saw a shift from the traditional bipolar system of the Second Republic to a "tripolar" system (Chiaramonte and Emanuele 2014; Tronconi 2015b). After this "electoral earthquake" (Chiaramonte and De Sio 2014), the beginning of the new cycle was marked by other critical political and electoral events: the replacement of Enrico Letta with Matteo Renzi in Palazzo Chigi (February 2014), the remarkable success of the Partito Democratico (PD, Democratic Party) in the European elections of 25 May 2014, and the difficulties that the PD subsequently experienced in the 2015 regional elections (Bolgherini and Grimaldi 2015; Tronconi 2015b).

These municipal elections fell midway through the 2013-2018 electoral cycle at what would normally be a less favorable time for governments in general due to the length of time elapsed since their initial victory and before the positive effects of their policies could be felt by voters (Stimson 1976). All this occurred in Italy within an economic context characterized by what was still a weak recovery and a political 
context in which public opinion continued to show disaffection vis-àvis the political class.

Given these premises, it is not surprising that the outcome of these elections brought the first real defeat for the PD since Renzi was voted in as party leader. In fact, after a first round of voting that led to the election of only a low number of mayors as a result of the tripolar nature of the system, the run-offs provided a clear result. They revealed the M5S as being among the winners of these municipal elections, having won all the run-offs but one in which it had a candidate standing, as well as "historic" victories in Rome and Turin. Meanwhile, the PD held on to its overall majority in terms of the number of councils under its control, including Milan, for which Renzi had fought hard, but it appeared to have suffered a political defeat, having lost one-fifth of its votes and half of the cities under its control compared with the previous council elections. Finally, the center-right, despite being in a critical stage of transition, succeeded in making slight gains compared to the previous elections, showing that when it is united, it can still be competitive. When it is divided, it frequently fails to make it to the run-offs, thereby opening the way for the M5S to seize victory in 2016 .

This chapter is structured as follows. The first section provides an outline of the electoral supply presented by the main political parties, looking at both the ways alliances were formed and the different methods used to select candidates. The second section analyzes the turnout and the results of the first-round votes in the comuni superiori (i.e., local councils with more than 15,000 inhabitants) in terms of victories, defeats, and run-offs in comparison with the previous round of local elections. The third section looks at the results of the run-offs, again comparing these with the previous round of local elections. The fourth section examines the vote shifts in the main cities by comparing votes cast in the first round in 2016 with those of the previous council elections, and by analyzing the ways in which votes shifted between the first and second rounds in 2016. The fifth section focuses on the results obtained by parties and coalitions and how votes have shifted since the previous municipal elections. The last section discusses the implications of these local elections for the national political system.

\section{The Electoral Supply}

Before moving on to an analysis of the election results, we must first consider the crucial factor of how the competition was composed. It is therefore appropriate to give a brief outline of the electoral supply 
presented by the main political parties, looking at both the structure of the alliances and the different ways in which candidates were selected.

Having seen the change from the bipolar system of the Second Republic to the new tripolar one that emerged after the general election of 2013, both at the national level (Chiaramonte and Emanuele 2014) and at the regional level (Tronconi 2015b), it would not have been surprising if there had been a radical change in the composition of the electoral supply in 2016 compared with the previous one in 2011, with an increased fragmentation in terms of the mayoral candidates and a reduction in the number of lists supporting each of them. Yet there were two systemic disincentives working against this change: the local electoral system, ${ }^{1}$ which encourages parties to form coalitions in order to obtain a majority premium, and the opportunity to cast a preference vote, which makes the multiplication of lists more attractive, thereby creating as large a pool of candidates as possible. It may be argued that these disincentives influenced the situation from the outset, given that the starting position was quite similar to the one in 2011, both in terms of the mayoral candidates (an average of 8.5 in the provincial capitals) and of the competing lists (22.2 on average). Contrary to expectations, the number of lists supporting candidates outside the two main coalitions - those that included the PD and Forza Italia (FI) - remained fairly stable (10.4). Yet the average number of lists within the two main coalitions was also still quite high: 5.8 for the PD-led coalitions and 6 for those led by FI. The FI figure is slightly lower than in 2011 (6.4), when it was still Popolo della libertà (PdL, People of Freedom), but it is surprising that this party, in spite of the center-right coalition's collapse in many cities, still managed to draw support from a variety of lists for its candidates. A more detailed analysis of the coalitions that included FI reveals how large a role was played by civic and local lists. Out of a total of 127 lists included in the coalitions in which Silvio Berlusconi's party appeared, more than 60 percent (77) were lists that did not run under the banner of national parties.

Another interesting feature was, of course, the great divergences in terms of the number of lists and candidates across the country. We can see a greater fragmentation in the lists in the South (an average of 26.1 lists compared with 18.1 in the Center-North), while the mayoral contests were more fragmented in the Center-North (an average of 8.9 candidates for each position of mayor compared with 8.2 in the South). In other words, whereas in the Center-North competition was particularly strong for the mayoralties, in the South the bigger battle was over obtaining seats in the council.

As for the structure of the alliances, we should begin by saying that the PD and FI invariably stood in coalition with other lists. FI did not 
stand in 16 of the 132 councils with more than 15,000 inhabitantsm, which enables us to draw comparisons with the past. ${ }^{2}$ In contrast, the M5S stood on its own for all the councils, presenting no candidates in less than 32 cities and in more than 90 percent of the comuni inferiorithat is, local councils with fewer than 15,000 inhabitants. With respect to the previous council elections, the old configuration of center-left versus center-right reached a critical point in many cities. One example of this is that the alliance between the PD and Sinistra Ecologia e Libertà (SEL, Left Ecology and Freedom) held in only seven provincial capitals. As far as the center-right is concerned, the old alignment that had been in place during the 20-year Berlusconi era collapsed in no fewer than eight provincial capitals, where FI and the Lega Nord (LN, Northern League) decided not to present a single mayoral candidate.

Finally, we would point out the considerable differences between the three main political poles (center-left, center-right, and M5S) as far as the method used to select candidates for the position of mayor in the main cities was concerned. The PD continued to use open primaries as its preferred method of selection, with the exception of places where they had incumbents standing for re-election (e.g., Piero Fassino in Turin and Virginio Merola in Bologna). In Milan, where the outgoing mayor Giuliano Pisapia did not stand for re-election, the coalition primaries attracted around 60,000 voters and produced a winning tally of 42 percent for Beppe Sala (formerly the EXPO 2015 commissioner), thanks to the support of Renzi and the majority of the party against the alternative left-wing candidates Francesca Balzani and Pierfrancesco Majorino. In Rome, the PD, in deep trouble after the resignation of the mayor, Ignazio Marino, put forward Roberto Giachetti (politically close to Renzi) as its candidate for the mayoralty, and he won the primaries with 60 percent against the left-wing PD member Roberto Morassut. Finally, in Naples there was a straight fight between the ex-mayor and president of the Campania region, Antonio Bassolino, and his "ex-protégée," Valeria Valente, who had the backing of the majority of the PD. She came out on top with 46.7 percent, but the contest was marked by bitter arguments and accusations of alleged irregularities in the polling stations.

The selection of candidates within the center-right was influenced by the decisions made by the national party leaders, as had always been the case during the Berlusconi era. The only exception was Latina, where the coalition organized open primaries that led to a victory for Nicola Calandrini of the far-right Fratelli d'Italia (FdI, Brothers of Italy). In Milan and in Bologna, the coalition presented single candidates, albeit with different profiles. Indeed, in the provincial capital of Lombardy, thanks to Berlusconi's input, the coalition was led by the 
city manager Stefano Parisi. In Bologna, however, a more radical figure was selected-the LN politician Lucia Borgonzoni. The center-right was split in Turin, Rome, and Naples, which led to dire consequences in terms of its ability to compete in the polls. In this sense, the case of Rome, where Berlusconi had attempted to force through the selection of Guido Bertolaso (ex-head of the Civil Protection Department) as a unifying candidate, was emblematic. The LN and FdI refused to fall in line, launching the candidacy of the FdI leader, Giorgia Meloni. At that point, Berlusconi himself, conscious of the fact that Bertolaso was lagging behind in the pre-election opinion polls, withdrew Bertolaso's candidacy, calling on the party to unite around Alfio Marchini, who was already standing with his own civic list.

As far as the M5S was concerned, the selection of candidates was not based on one single model. While from a formal point of view the choice was left to the M5S's local activists when they held their meetup sessions, in reality the main nucleus of the party sometimes played a decisive role. In Turin and in Rome, the two candidates for the position of mayor, Chiara Appendino and Virginia Raggi (M5S councilors in their respective cities), immediately emerged as the front-runners. However, in Milan and in Naples, the choice was less straightforward. In Milan, shortly after winning the special primaries open only to local M5S members, known as comunarie, the activist Patrizia Bedori withdrew as a result of media pressure, and the M5S leaders selected the Neapolitan Gianluca Corrado, who had come in third in the comunarie. In Naples, on the other hand, a member from Brianza, Matteo Brambilla, was selected as the M5S candidate, having mustered 48 percent of the votes in the comunarie. Finally, the councilor Max Bugani was selected to stand as the mayoral candidate in Bologna without the use of M5S's online primaries. Bugani is one of Beppe Grillo's closest allies and a member of the Rousseau Association-the nerve center of the M5S's IT system.

\section{Turnout and the First Round of Voting}

The first statistic to consider when analyzing the outcome of the vote is the one concerning turnout. In the larger cities, turnout reached 60 percent, a fall of 5 percentage points compared with the previous council elections (see table 1). If we break this figure down to examine the turnout in various geopolitical areas, we can see a very big drop in the North and in the Center ${ }^{3}$ compared with the previous council elections (down 10 percentage points), but a fairly stable position in the South (down only 2 percentage points). The figure is skewed, however, by the 


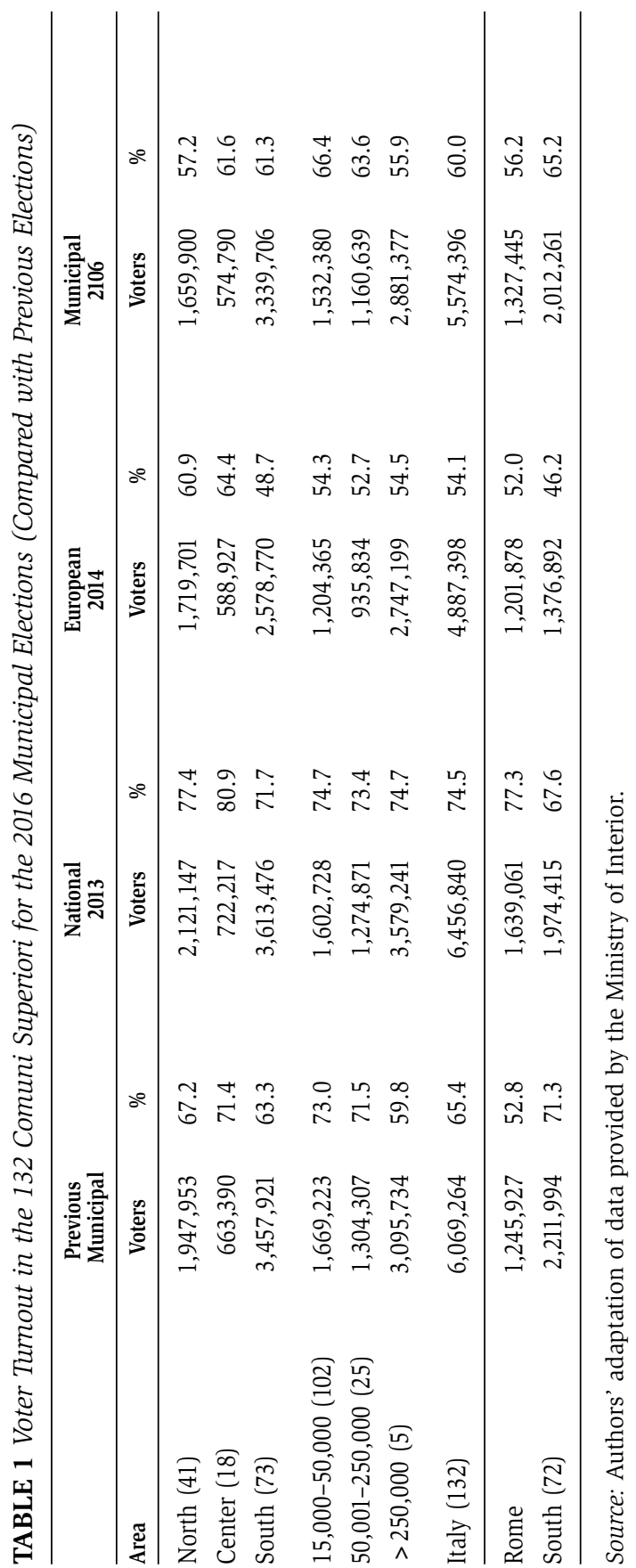


fact that the Rome council alone carries greater weight than the rest of the South combined. In fact, our interpretation is completely different if we take out the figure for the capital. The South without Rome shows a markedly higher level of participation than the rest of the country- 65.2 percent, 8 points higher than in the North-but it still shows a clear drop of 6 percentage points from the previous council elections. If we compare turnout with the European elections of two years ago, the geography of participation levels has been turned upside down: there has been a fall in the number of voters in the North (down 3.7 percentage points) and in the Center (down 2.8 percentage points), while there has been a clear increase in the South (up 19 points, excluding Rome), which has brought the overall national figure up by 5.9 percentage points. These differences highlight the peculiar nature of municipal elections, where the personal vote-expressed through the casting of the preference vote, as well as the vote for the mayoral candidatesis very important, especially in the South, whereas in the European elections the preference vote is a reflection of opinions and national politics. In this context, it is not surprising to observe that, in line with the preceding municipal elections, turnout was inversely proportional to the size of the cities. In councils with populations of between 15,000 and 50,000 inhabitants, an average of 66.4 percent of the electors cast their vote, compared with only 55.9 percent in the five largest cities. By contrast, if we analyze the data for the last national election and European elections, the demographic dimension had no influence whatsoever on turnout. This proves that municipal elections are much more keenly felt in the smaller towns, especially in the South.

If we take out the figures for the 24 provincial capitals where elections took place, ${ }^{4}$ turnout was 57.6 percent, nearly 5 points less than the overall figure for the councils that were not provincial capitals and a drop of almost 5 points compared to the previous municipal elections. The turnout figures of more than 70 percent in some southern towns (Benevento, Cosenza, Crotone, Caserta, and Latina) stand out. In contrast, turnout was low in Rome ( 56 percent), Milan (55 percent), Naples (54 percent), and Trieste (57 percent). Curiously, Rome is the only provincial capital in which turnout increased compared to previous municipal elections (up 3.3 percentage points), while there was a steep fall in Milan (down 13 points), Cagliari, Olbia, and Bologna (down around 12 points). By and large, the 2016 municipal elections did not see a collapse in turnout but a fall that is more or less "physiological," in line with the general trends of recent years.

Looking beyond turnout, the key topic to consider when assessing local elections is that of winners and losers. One good method to adopt is to look first at the starting point (see table 2). Of the 132 large 
councils, the center-left (i.e., the coalitions led by the PD) registered 84 victories in the previous municipal elections, compared to the 29 won by the center-right (i.e., coalitions led by the PdL/FI). This implies that Italy still had a largely bipolar situation (with fewer than 15 percent of councils being run by mayors supported by coalitions not led by the two main ones), in which the traditional center-left ${ }^{5}$ occupied an advantageous position over Berlusconi's center-right, which was already on the decline, while the M5S was still on the margins of politics.

The number of councils that saw an outright victory in the first round of the 2016 elections was cut by half, an outcome that occurred in only 21 of the 132 comuni superiori, compared with 40 in the previous elections. This provides a clear sign that the political context had changed over the five-year period. It is of course the result of the transformation of the Italian party system toward three poles, as well as the fragmentation of the political offer. In the council elections in which there was a decisive result in the first round, the center-left won 11 (including Rimini, Cagliari, and Salerno), and the center-right 7 (including Cosenza). Two councils came under the control of civic lists, and one under the LN. The positive result achieved by the PD-led coalitions can be seen not only in the number of councils it won control of in the first round, but also in the strong position that Renzi's party built for the run-offs (see table 2). As far as these were concerned, the contest in 42 of the 111 cities was the one traditionally held in the Second Republic between the PD-led center-left and the FI-led center-right. There were only 11 cities (i.e., 10 percent of the councils) where a Rome-style contest between center-left and M5S would be fought, even fewer than the 13 cities where there would be contests between center-left and civic lists.

\section{The Results of the Run-Offs: Who Won and Who Lost?}

Considering the small number of councils that were won in the first round, the run-offs became the key test to see who were the winners and losers in the 2016 municipal elections. The starting point for our analysis concerns the number of victories obtained in the run-offs in the 111 cities with more than 15,000 inhabitants (see table 3). The center-left won in 31 cities, while the center-right won in 26, the M5S in 18 , civic lists in 14 , right coalitions in 9 , left coalitions in 6 , and center coalitions in 5 . These results were produced by a turnout of 51.3 percent, which was 10.7 percentage points lower than in the first round.

These run-offs were detrimental for the PD because it won in fewer than half of them (to be precise, in 36.9 percent of them). The centerright, on the other hand, won in 47.3 percent of the run-offs in which 
TABLE 2 Winners in the 1st Round and Presence in the 2nd Round of the 2016 Municipal Elections (Compared with Wins in Previous Municipal Elections), 132 Comuni Superiori

\begin{tabular}{lccc}
\hline & $\begin{array}{c}\text { Wins in Previous } \\
\text { Municipal Elections }\end{array}$ & $\begin{array}{c}\text { Won in 1st } \\
\text { Round, 2016 }\end{array}$ & $\begin{array}{c}\text { Reached 2nd } \\
\text { Round, 2016 }\end{array}$ \\
\hline Center-left & 84 & 11 & 84 \\
M5S & 0 & 0 & 19 \\
Center-right & 29 & 7 & 55 \\
Right & 3 & 1 & 13 \\
Left & 6 & 0 & 8 \\
Center & 4 & 0 & 7 \\
Civic lists & 6 & 2 & 28 \\
Other center-left & 0 & 0 & 6 \\
Other center-right & 0 & 0 & 2 \\
\hline Total (municipalities) & 132 & 21 & 111 \\
\hline
\end{tabular}

Note: By "left" we refer to coalitions supporting candidates outside the PD (SEL, SI, FdS, and allied groups); "center-left" denotes the coalitions led by the PD; "center" includes the coalitions formed by UdC and/or NCD and minor allied groups; "center-right" denotes the coalitions led by FI; "right" includes the coalitions formed by the LN and/or the FdI with minor allied groups but not FI; "other center-left" covers the three coalitions led by the PSI; "other center-right" denotes two coalitions led by Raffaele Fitto's CR.

Source: Authors' adaptation of data provided by the Ministry of Interior.

TABLE 3 Winners of the 2016 Municipal Elections, 132 Comuni Superiori

\begin{tabular}{lccc}
\hline & $\begin{array}{c}\text { Wins in } \\
\text { 1st Round }\end{array}$ & $\begin{array}{c}\text { Wins in } \\
\text { 2nd Round }\end{array}$ & $\begin{array}{c}\text { Total } \\
\text { Wins }\end{array}$ \\
\hline Center-left & 11 & 31 & 42 \\
Center-right & 7 & 26 & 33 \\
M5S & 0 & 18 & 18 \\
Right & 1 & 9 & 10 \\
Left & 0 & 6 & 6 \\
Center & 0 & 5 & 5 \\
Civic lists & 2 & 14 & 6 \\
Other center-left & 0 & 1 & 1 \\
Other center-right & 0 & 1 & 132 \\
\hline Total & 21 & 111 &
\end{tabular}

Source: Authors' adaptation of data provided by the Ministry of Interior. 
it was involved. If we look at the 42 straight contests between centerleft and center-right, the center-right prevailed in 23 of them, while the center-left won 19. Thus, the scales were tipped in favor of the centerright in the contests between the two coalitions that had traditionally opposed one another in the Second Republic. The performance of the M5S was striking: it won 18 run-offs out of 19, beating all of its centerright and center-left opponents and losing in just one (Alpignano in Piedmont), where it was beaten by a coalition of civic lists.

If we now take a closer look at the results in the 20 provincial capitals where run-offs were held (see the appendix in this volume), the outcome is even clearer: the FI-led center-right won in 6 cities (Benevento, Grosseto, Olbia, Pordenone, Savona, and Trieste), the PD-led center-left won in 5 (Caserta, Bologna, Milan, Ravenna, and Varese), the M5S in 3 (Carbonia, Rome, and Turin), and the right coalitions in 2 (Isernia and Novara). In Naples there was a victory for the left coalition led by Luigi De Magistris, while a centrist coalition won in Crotone, a civic list won in Latina, and a minor center party (not allied to FI) won in Brindisi.

Looking beyond the numbers, however, the victories obtained by the M5S in Turin and in Rome took on particular significance from a symbolic and political point of view and were seen as "weighty" and historic. Raggi swept to power with more than 67 percent of the votes, thereby becoming Rome's first female mayor. Appendino also achieved an emphatic victory in Turin, a city that had been under center-left control for 20 years. If we examine the actual number of votes, Raggi picked up more than 309,000 votes in Rome between the first and second rounds, while Giachetti gained 51,100. A similar increase in M5S votes could be seen in Turin, where the figures are even more striking. Votes for Appendino increased markedly by more than 84,000, while Fassino more or less held on to the same number of votes he had achieved previously. All this took place within a context where voter numbers dipped slightly compared with the first round (54.6 percent, down 2.8 points), making Turin the city with the lowest drop in turnout. By contrast, second-round turnout in Rome was just 50.2 percent-a drop of almost 7 points compared to the first round.

The case of Milan is rather different, showing again how local factors play an important role. Sala managed to secure an important victory in the economic and financial capital of the country, even from a symbolic point of view, making the overall results obtained by the PD in the second round less disappointing. Sala defeated his center-right opponent, Parisi, with 51.7 percent of the votes, which also meant that he had achieved more of an improvement than Parisi between the first and second round. We should also bear in mind that Milan is the city 
where, after Turin, turnout dropped less dramatically between the first and second rounds (turnout was 51.8 percent in the run-offs, down 2.9 points). The PD also won in Bologna, where Merola was re-elected as mayor, gaining the support of 54.6 percent of the voters despite the surge in votes for Borgonzoni between the first and second round.

The most significant result in the South was undoubtedly the one in Naples, where De Magistris obtained a clear victory (with 66.9 percent of the votes) against the center-right candidate Gianni Lettieri. However, we should also point out that Naples is the provincial capital that saw the lowest turnout in the run-offs ( 36 percent). The fact that just over a third of the voters decided to go to the polling stations is a clear sign of the widespread disaffection with politics among Neapolitans.

To recap, if we also take into account the mayors voted in after the first round, a comprehensive count of victories and defeats in the councils with more than 15,000 inhabitants reveals that the center-left won in 42 councils, the center-right in 33 , the M5S in 18 , civic lists in 16, right coalitions in 10, left coalitions in 6, and center coalitions in 5 (see table 3). ${ }^{6}$ So while it is true that the PD won in more councils than its opponents, this is only a numerical victory and not a political one. This becomes even more apparent if we compare the results with those of the municipal elections in 2011 (see table 4). The center-left, in fact, lost half of the councils that were previously under its control (42 in 2016 compared with 84 previously), while the center-right made gains (33 in 2016 compared with 29 previously), and the M5S took more than 18. This is a clear sign that the Italian party system was undergoing a transformation and becoming tripolar (Chiaramonte and Emanuele 2014).

TABLE 4 Winners in the 2016 and Previous Municipal Elections

\begin{tabular}{lcc}
\hline & $\begin{array}{c}\text { Wins in Previous } \\
\text { Municipal Elections }\end{array}$ & $\begin{array}{c}\text { Wins in 2016 } \\
\text { Municipal Elections }\end{array}$ \\
\hline Center-left & 84 & 42 \\
Center-right & 29 & 33 \\
M5S & 0 & 18 \\
Right & 3 & 10 \\
Left & 6 & 6 \\
Center & 4 & 5 \\
Civic lists & 6 & 16 \\
Other center-left & 0 & 1 \\
Other center-right & 0 & 1 \\
Total & 132 & 132 \\
\hline
\end{tabular}

Source: Authors' adaptation of data provided by the Ministry of Interior. 


\section{Vote Shifts}

The data provided by the Centro Italiano Studi Elettorali (CISE, Italian Center for Electoral Studies) enable us to identify the vote shifts for mayoral candidates in the main cities by comparing the first round in 2016 to the same round in the previous municipal elections (Emanuele et al. 2016). A few interesting elements can be clearly identified.

First of all, the Italian electorate is extraordinarily volatile. If we analyze the votes in four of the largest cities (Milan, Turin, Naples, and Bologna), only three mayoral candidates managed to obtain at least 60 percent of the votes of those who had voted for them in the previous municipal elections. These three were De Magistris in Naples (67 percent), Parisi in Milan (the center-right candidate who attracted the votes of 63 percent of those who had voted for the previous centerright mayor, Letizia Moratti), and Appendino in Turin (the M5S winning candidate who gained 60 percent of the votes previously cast for the M5S candidate Vittorio Bertola). All the other candidates succeeded only in remobilizing the electorate in their part of the political spectrum. This phenomenon applied to all the parties, including the center-left, whose voters had traditionally been more stable (Cataldi et al. 2012). Merola achieved repeat votes from 52 percent of PD voters in Bologna, but in other cities PD candidates recaptured fewer than half of their (ex-)voters: Sala got 48 percent and Fassino 42 percent, while Valente managed only 29 percent in Naples.

Second, there appears to be a "genetic mutation" in the PD electorate (Cataldi and De Sio 2016). Renzi's party has steadily surrendered significant support to the M5S, although it has gained some from the center-right. This trend would appear to be the logical consequence of the political line adopted by the party secretary. In Turin, a third of the votes obtained by Fassino in 2011 went over to Appendino, while a third of the votes the ex-mayor gained in 2016 were cast by centerright voters. In Naples, a greater number of votes for Valente came from the center-right than from the PD's candidate in 2011 (Paparo and Cataldi 2016). The same occurred to a lesser extent in Milan, where a quarter of Sala's votes came from Moratti's supporters, while in Bologna the M5S candidate Bugani picked up about half of his votes from people who had previously voted for the PD.

Finally, we have identified an important change within the M5S electorate: instead of seeing the traditional "transversal" appeal of the movement, that is, its ability to pull in votes equally from the right and from the left (Maggini and De Lucia 2014), the M5S candidates in the first round of the 2016 municipal elections drew most of their support from the left. In fact, if we look at where their votes came from, there is a 
large imbalance between those who moved over to them from the left as opposed to ex-right voters. In Milan and Turin, for every voter switching from the center-right to vote for Corrado and Appendino, there are about 10 switching from the center-left. In Bologna, where half of Bugani's support came from the center-left, there is no leakage of votes from the center-right toward the M5S (D’Alimonte et al. 2016). It was only in Naples that a greater balance was to be found, with the center-right contributing 31 percent of the votes for the M5S candidate Brambilla, compared with the 45 percent coming from the De Magistris and the $\mathrm{PD}$ area. Nevertheless, in the run-offs the M5S regained the transversal capacity that it has always displayed, picking up votes from the right.

Moving on to an analysis of the shifts in voting patterns between the first and second rounds (see table 5), we can see that in Turin, for example, Appendino walked away with the center-right votes: 98 percent switched to her from Area Popolare (AP, Popular Area), 85 percent from FI, and 71 percent from the LN and the FdI. All this occurred in a context where there were few abstentions. By contrast, Fassino failed to attract the wholehearted support of those on his left (only 47 percent of those who had previously voted for the left candidate Giorgio Airaudo), nor did he pick up many votes from people to his right.

If we now examine the case of Naples, De Magistris managed to win largely by remobilizing the support of 92 percent of those who had voted for him in the first round. As happened five years earlier (Cataldi et al. 2012), Lettieri received repeat votes from fewer than two-thirds of his first-round supporters, with 38 percent of them opting not to vote at all, and obtained virtually no support from M5S voters.

In Milan, Sala won not only because he succeeded in persuading his first-round voters to go back to the polling stations, but also because he picked up the votes of 91 percent of the 19,000 people who had supported Rizzo, the radical left candidate. These votes turned out to be decisive, given that the winning margin between Sala and Parisi was 17,000 votes. Another interesting feature in Milan was the behavior of the M5S voters, who abstained en masse (88 percent, to be exact). Only a handful of them voted for Parisi, and virtually none of them, allowing for statistical error, voted for Sala.

In Bologna, the M5S supporters shifted more toward the center-right candidate. Around 45 percent of them voted for Borgonzoni, while only 10 percent chose Merola. But once again, many of them abstained from voting in the second round. To sum up, the data from Naples, Milan, and Bologna confirm what had already emerged on other occasions: it is more likely that an LN supporter will vote for an M5S candidate than vice versa. There is no symmetry between center-right voters and M5S voters. 


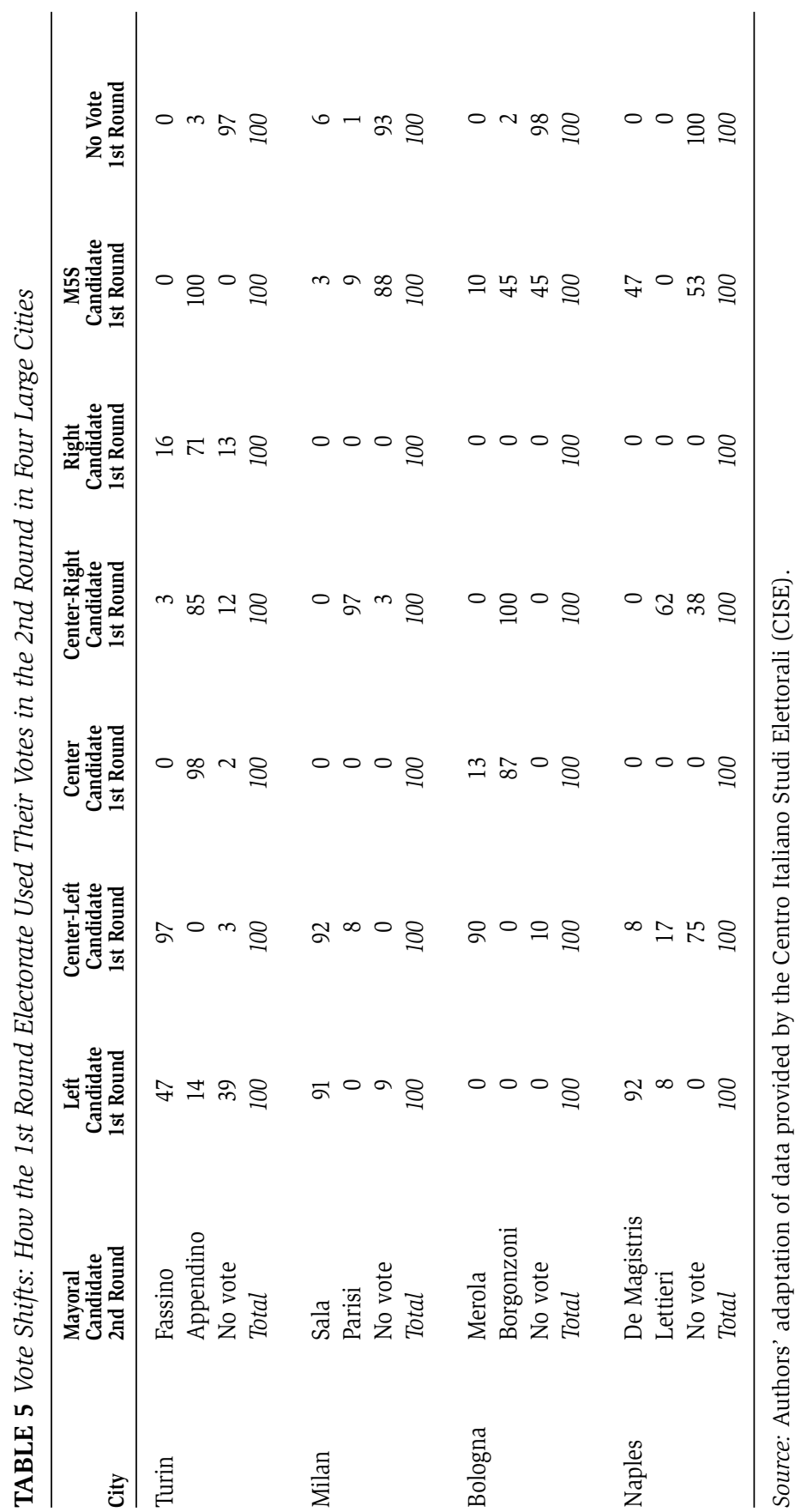




\section{Results for Parties and Their Political Areas}

The overall results in the 132 municipalities where polling took place enable us to provide a full assessment of the outcome of the 2016 elections and of the performance of Italian political parties, looking beyond the emphasis placed by commentators-inevitably so-on the most important cities where contests were held. However, it is important to point out that the national picture that emerges is not fully representative of the country. First of all, our analysis gives particular weight to the large urban centers and does not include councils with fewer than 15,000 inhabitants, even though these make up around 40 percent of the Italian electorate. Also, the South is over-represented, as it accounts for 60 percent of the voters in the 132 municipalities, whereas its actual proportion in the country is around 46 percent. This leads to a systematic over-representation of the strong parties in the large urban centers and of parties rooted in the South and consequently an under-representation of the parties, such as the Northern League, whose support is drawn largely from the smaller towns and in the Center-North (Emanuele 2011).

The top part of table 6 shows the results obtained by the parties in the proportional system, while underneath are the votes for the mayoral candidates from the different political areas. If we look at the results for the parties, we can see that the PD was confirmed as the largest party in Italy, even though its share fell by almost 4 points to 18.8 percent compared with the previous municipal elections. This drop was partially offset due to gains made by some minor lists supporting PD-backed candidates, which increased by more than 3 percentage points, but there was still a net loss. In any event, the "PD area"-the PD and lists allied to it, that is, local civic lists and personal lists for mayoral candidates approved by the PD-picked up 30.9 percent of the votes. Looking now at the lower part of the table, the candidates supported by the PD achieved a relative majority of the votes, gathering just less than a third of the total ( 32.2 percent). This means a drop of around 8 points compared with the two-pole scenario of the previous municipal elections. Nevertheless, the center-left candidates continued to obtain the most votes-more than 10 points more than candidates supported by FI and almost 14 points more than M5S candidates. This is clear evidence that the PD was the party best able to build competitive coalitions around itself.

The collapse of FI was much more dramatic, falling by 10 points to just 7.2 percent of the proportional vote. In reality, Berlusconi's party stayed afloat only in Milan, where it obtained 20 percent, more than a quarter of all its votes. Overall, the "FI area"-FI and other center-right 


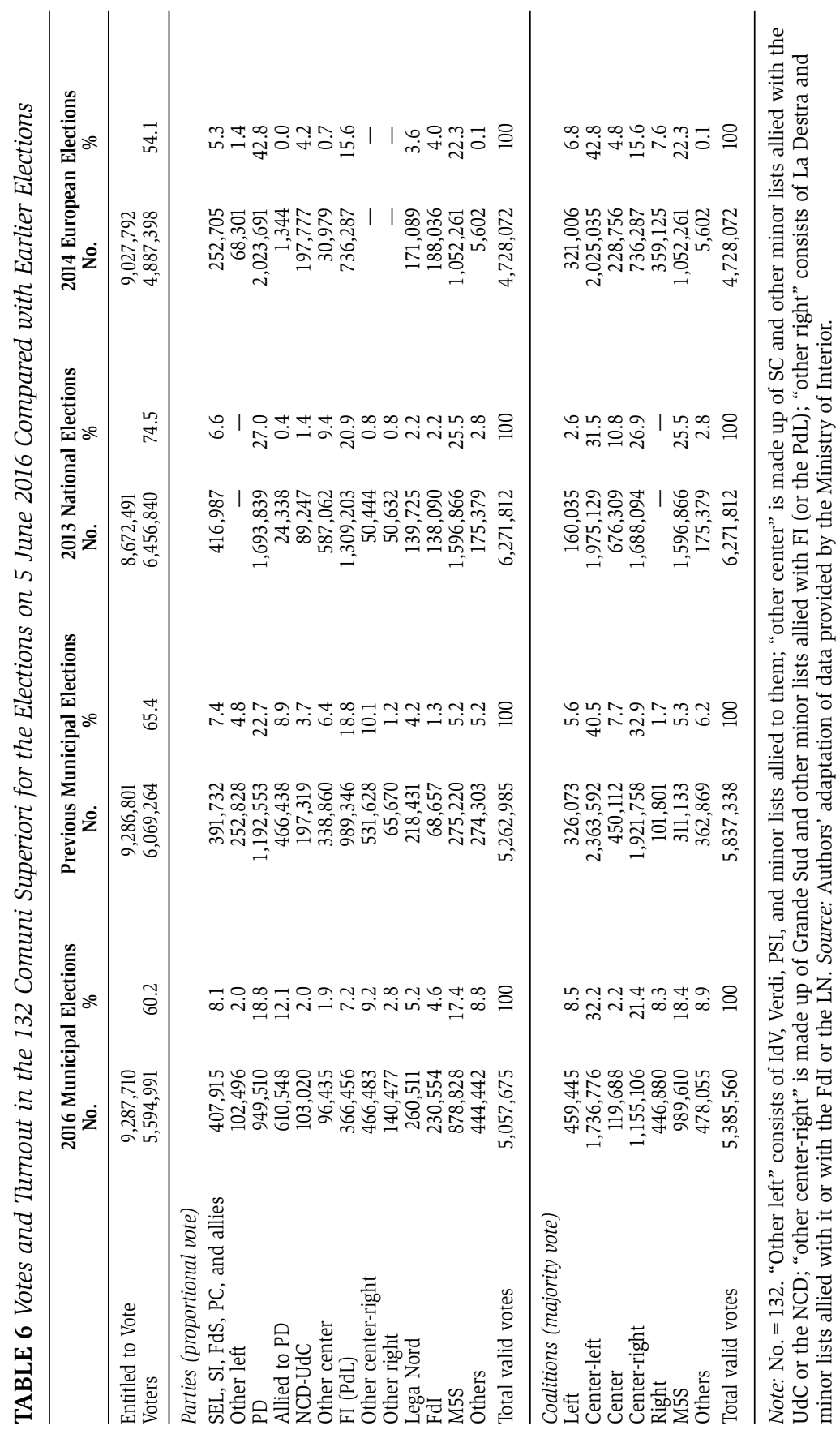


lists allied with it, that is, civic lists or personal lists for mayoral candidates supported by FI-mustered 16.4 percent, just over half of what the PD area achieved. The results for the mayoral candidates supported by FI were decidedly better, reaching 21.4 percent. There was a fall of more than 10 points in the majority vote compared with the previous municipal elections, but it should be pointed out that the center-right presented no candidates in 16 of the 132 municipalities.

The M5S took second place in the proportional vote with 17.4 percent, a three-fold increase since the previous municipal elections. However, if we look at the mayoral vote, and if we disregard the outstanding results the M5S achieved in Rome and Turin, its candidates were often excluded from the run-offs, albeit with some respectable vote shares (18.4 percent).

Moving our focus now to the other parties, the LN, which was inevitably at a disadvantage in this set of municipalities, grew by one percentage point, reaching 5.2 percent if we also factor in the votes for the Noi con Salvini lists. ${ }^{7}$ The FdI's performance was very good, moving up from 1.3 percent in the previous municipal elections to 4.6 percent. In the majority vote, the candidates representing the right outside FI obtained just over 8 percent, virtually equaling the result of left candidates outside the PD. This represented an improvement for both political areas compared with five years ago, although it was largely due to the pulling power of particular candidates: Meloni's result in Rome makes up 60 percent of the entire right vote, while De Magistris in Naples accounts for 37 percent of the left vote. In both cases, their ambition to compete with the larger party close to them in the political spectrum was dashed by the results of these municipal elections. In fact, the PD was still the largest party in the center-left area, in spite of the fact that Renzi's emergence as leader opened up new room for maneuver on the left and allowed for more candidates to stand as alternatives to the PD, often with modest results. On the other side, the attempt by the LN and FdI to shift away from Berlusconi certainly needs to be revisited, and, in this regard, the failure of the right in Rome is emblematic. The center area, moreover, had to settle for a secondary role, squeezed as it was between the PD's centrist strategy, the fragmented center-right offer, and the advance of the M5S.

One final point is worth making. Almost half a million votes, 8.9 percent, were cast for civic candidates, that is, candidates who did not belong to or were not supported by any one party. This degree of success for civic candidates was unprecedented, and yet it took place in a context where a party like the M5S, defining itself as the "voice of the citizens," also grew enormously. 


\section{From Local to National: What Are the Implications for the Political System?}

The municipal elections that we have analyzed in this chapter provide some useful points for reflection in terms of voting trends at this delicate time for Italian politics. Interpreting the results takes us beyond the role played by purely local factors, which certainly had a bearing on them, and we can see how they fall in line with the analytical model for second-order elections (Reif and Schmitt 1980). As we said at the outset, it was always likely that the results would not be positive for the PD, since these elections were held just over midway through their mandate, that is, at the point where the popularity of governments is typically at its lowest (Stimson 1976). Indeed, the results tell us that the PD has paid a real price in terms of the "cost of ruling" (Paldam 1986).

In any event, even taking into account these premises concerning the broader state of affairs in which the municipal elections took place, it cannot be denied that they produced the first real defeat for the PD since Renzi was elected as party secretary. Compared with the previous municipal elections, the party lost more than one-fifth of its support and surrendered half of the councils it had controlled. Nevertheless, the PD can find consolation in some of the figures. It is still the party around which the winning coalitions for the largest number of councils were built. It also emerged with victories in important cities of the North, in particular Milan and Varese. It is the party that obtained the most votes overall, although partly because the M5S did not stand in all the municipal elections. The fall in support for the governing center-left was not exploited by the parties closest to it on the left-right axis. In fact, the alternatives to the left and center of the PD failed to make any inroads.

Contrary to pre-election expectations, the traditional center-right, consisting of FI and its allies, managed to hold its ground, proving to be especially competitive in places where it put forward a single candidate. In this sense, its most noteworthy successes were the victories in Trieste, Pordenone, and Savona, but it also achieved a good result in Milan. Having said that, the center-right often fell short of the run-offs in places where FI and the LN ran with separate candidates.

It was actually the divisions within the conservative pole that opened the way for the two crucial victories achieved by the M5S in Rome and Turin, which have affected the overall interpretation of these elections to some degree. There is no doubt that the M5S should be considered the winner of these municipal elections, even though it took control of far fewer councils than the two main poles. Its votes 
increased threefold, and it showed that it is (almost) invincible when it reaches the run-offs, making the most of being a "catch-all" party, the real "party of the nation" that is able to attract votes from all parts of the political space. This characteristic enables the M5S to occupy a pivotal position between what used to be the two large poles, thus picking up the second preferences in the run-offs of those voters whose first-choice candidates lost. It is often these second preferences that determine the outcome of the second rounds, as exemplified in the cases of Rome and Turin, where Raggi and Appendino succeeded in winning over large numbers of center-right voters. While the PD's defeat in Rome was foreseeable in light of problems at the local level, the result in Turin was a surprise and set alarm bells ringing for the PD at the national level, making this one of the most significant outcomes of these elections from a political point of view. In brief, the results for the M5S cannot be attributed purely to local factors.

Lastly, the M5S's success has important implications for the Italian party system: it has changed from being a bipolar system, as in the previous municipal elections, to a system with at least three poles, like the current one. That is to say, the tripolar system has now taken root at the local level, after establishing itself on the national level with the general election of 2013.

- Translated by David Bull

Vincenzo Emanuele is Postdoctoral Fellow in Political Science at the LUISS Guido Carli in Rome.

Nicola Maggini is Research Fellow at the University of Florence. 


\section{Notes}

1. The electoral system for towns in Italy with more than 15,000 inhabitants requires that mayors and councilors be elected directly. Mayors are elected through a "majority" system, that is, they must gain an absolute majority of the valid votes in the first round, failing which there is a run-off between the two candidates with the most votes. Councilors are elected through a proportional system by gathering votes on an open list. Furthermore, there is a majority bonus for the coalition of lists that supports the winning mayor. Except in rare cases, this bonus gives the mayor a majority in the council.

2. The other 11 towns with more than 15,000 inhabitants (Altopascio, Anguillara Sabazia, Bovolone, Bracciano, Caravaggio, Caronno Petrusella, Cirò Marina, Codogno, Corbetta, Laterza, Rocca di Papa) are excluded from the analysis because no comparison is available with previous council elections: these towns had fewer than 15,000 inhabitants at that time, had one only round of voting, and were subject to different electoral rules. The six towns in Sicily with between 10,000 and 14,999 inhabitants are also excluded because, although they are considered comuni superiori under regional Sicilian law, they hold only one round of elections.

3. The Center consists of four regions (Emilia-Romagna, Tuscany, Umbria, and Marche) that were formerly called the "red" belt because they traditionally voted for the left.

4. The town of Villacidro has been excluded from the analysis because it has fewer than 15,000 inhabitants.

5. The center-left was made up of the PD, SEL, and Italia dei valori (IdV, Italy of Values).

6. Note that if we also include the 11 towns that had fewer than 15,000 inhabitants when the previous elections were held, the final count of victories is as follows: center-left 45 , center-right 37 , M5S 19 , civic lists 19 , right coalitions 10 , left coalitions 6 , center coalitions 5 .

7. For more on Noi con Salvini, see the chapter by Vampa in this volume.

\section{References}

Bolgherini, S., and S. Grimaldi, eds. 2015. Tripolarismo e destrutturazione: Le elezioni regionali del 2015. Bologna: Istituto Cattaneo.

Cataldi, M., and L. De Sio. 2016. "Radiografia di una mutazione genetica: I flussi elettorali a Torino.” In Emanuele et al. 2016, 61-64.

Cataldi, M., V. Emanuele, and A. Paparo. 2012. "Elettori in movimento nelle Comunali 2011 a Milano, Torino e Napoli." Quaderni dell'Osservatorio Elettorale 67: 5-43.

Chiaramonte, A., and L. De Sio, eds. 2014. Terremoto elettorale: Le elezioni politiche del 2013. Bologna: Il Mulino. 
Chiaramonte, A., and V. Emanuele. 2014. "Bipolarismo addio? Il sistema partitico tra cambiamento e de-istituzionalizzazione." In Chiaramonte and De Sio 2014, 233-262.

D’Alimonte, R., M. Cataldi, and A. Paparo. 2016. "Il M5S avanza pescando dal centrosinistra: I flussi elettorali a Milano e Bologna.” In Emanuele et al. 2016, 69-73.

Emanuele, V. 2011. "Riscoprire il territorio: Dimensione demografica dei comuni e comportamento elettorale in Italia." Meridiana 70: 115-148.

Emanuele, V., N. Maggini, and A. Paparo, eds. 2016. Cosa succede in città? Le elezioni comunali 2016. Rome: Centro Italiano Studi Elettorali.

Maggini, N., and F. De Lucia. 2014. "Un successo a 5 stelle.” In Chiaramonte and De Sio 2014, 173-201.

Paldam, M. 1986. “The Distribution of Election Results and the Two Explanations of the Cost of Ruling." European Journal of Political Economy 2 (1): $5-24$.

Paparo, A., and M. Cataldi. 2016. "L'avanzata prorompente di un nuovo leader? L’analisi dei flussi a Napoli.” In Emanuele et al. 2016, 65-68.

Reif, K., and H. Schmitt. 1980. "Nine Second-Order National Elections: A Conceptual Framework for the Analysis of European Election Results." European Journal of Political Research 8 (1): 3-44.

Stimson, J. A. 1976. "Public Support for American Presidents: A Cyclical Model.” Public Opinion Quarterly 40 (1): 1-21.

Tronconi, F., ed. 2015a. Beppe Grillo's Five Star Movement: Organisation, Communication and Ideology. Aldershot: Ashgate.

Tronconi, F. 2015b. "Bye-Bye Bipolarism: The 2015 Regional Elections and the New Shape of Regional Party Systems in Italy." South European Society and Politics 20 (4): 553-571. 